\title{
Study the Impact of Quality Management System ISO 9001on Machinery Breakdowns
}

\begin{abstract}
Ameen Zahra
Textile Eng. Dep. Albaath University SYRIA

ameen.zahra6@gmail.com

Received: 08-Oct.-2018

http://doi.org/10.29194/NJES.21040539

Abstract

This research focuses on studying the importance of quality management system ISO 9001: 2015 and its impact on machinery breakdowns in the general company for the manufacture of wool and carpets in Hama for reducing the machines stops and thus increasing production quantities in the company. We did a field study in the company which a random sample of workers was interviewed in, taking into consideration the characteristics of the categories of workers.

We analyzed the data obtained from the workers by using statistical analysis program (SPSS19).

The statistical results have shown that there is a strong correlation between the quality management system ISO 9001: 2015 and machinery breakdowns, which necessitates giving greater attention to the ISO 9001 standard by the company's management and seeking ISO 9001 certification to achieve high performance for the company under study.
\end{abstract}

Jamil Chikh Osman
Industrial Eng. Dep.

Faculty of Chemical and Petroleum Eng. Faculty of Mechanical Eng. Faculty of Chemical and Petroleum Eng.
Aleppo University

SYRIA

j.quality2010@hotmail.com

\author{
Hussein Baker \\ Textile Eng. Dep.
}

Albaath University SYRIA

hussainbakr1@hotmail.com
Revised: 30-Oct.-2018 Accepted: 20-Dec.-2018
Keywords: Quality, Quality Management System ISO 9001, Machinery Breakdowns.

\section{1-Introduction:}

Quality is one of the most important requirements of the industry in modern companies today, and is one of the main means to maintain the centers of those companies in the market of industry, and quality has become among the subjects that occupy a large area in the thinking of departments after realizing that the increase of market share and growth of revenue and profitability mortgaged to the extent of their ability to produce goods to achieve customer satisfaction, and focus on quality leads to attention to reduce damage and try to prevent the occurrence, so the quality of a wide and distinctive area focused by many interested in the concept and application, which led to the emergence of multiple views on the concept of quality and definition [1], The most important definitions of quality:
- The American Quality Association defines it as: a set of advantages and characteristics of a product or service capable of meeting the needs of consumers [2].

- ISO defines it: the set of characteristics of an entity (activity, process, product, service, organization, system, person, or combination thereof) that make it meet or able to meet the stated and expected needs [3]. Juran has given his famous definition of quality as: Product fit for use [4].

- Crosby defined it as conforming to requirements or specifications and that quality can be measured by the cost of nonconformity. Deming described it as an expected degree of symmetry, reliability, low cost, and market fit, and this is in line with the definition of ISO [5].

- Marketing men usually look at quality through the consumer's view and satisfaction with the product, while the production men look at the quality of the manufacturing through the extent to which goods or services conform to standards or specification [6].

- Quality can be seen through three angles [7]:

1- Quality of design: a quality specification that is developed when designing the product.

2- Quality of production: the specifications that are achieved during the process of production itself.

3- Quality of performance: The quality that appears to the consumer when the actual use of the product.

In addition to excellence in providing the product or service and called the quality of customer service.

- The following comprehensive definition of quality can be adopted:

Quality: it is the availability of all specifications and characteristics in the product or service, which meet the requirements and needs of the client that are declared and implicit in a timely manner, and the appropriate price at the same time, and involved in the manufacture and construction of all employees and at all levels. 


\section{-ISO Concept:}

ISO is defined in terms of the meaning of the word as: equivalence, equality and similarity, a word derived from Greek origin (ISOS) which means equality, derived from the idea of non-difference [8].

The word ISO is derived from the first three letters of the International Organization for Standardization, a global federation of national standardization organizations. Because of the fact that there are many abbreviations for ISO in many languages, for example, in English, the abbreviation IOS and the French abbreviated $(\mathrm{ONI})$, so it was decided to adopt one abbreviation from the Greek word (ISOS) and became the standard abbreviation for all countries (ISO) [9].

ISO can be defined as: an organization whose mission is to produce international standard specifications and standardization in various fields at the global level, so as to facilitate the trade in goods and services and to develop cooperation among the countries of the world [10].

ISO is the world's most important body to oversee the development and production of international standards, called the ISO standard, a set of internationally recognized technical specifications for operating and managing the production processes and commodities [11]. Where the organization was founded in 1946 after World War II after a meeting of 25 countries in the capital London, and began its work in 1947 and headquartered in the Swiss capital Geneva, and the membership of more than 150 members representing the member countries of the organization [12].

Among the facts related to the organization, we mention the following: A non-governmental organization, the organization does not intervene in granting the institutions the certificate of conformity, where there are special bodies that grant this certificate, the organization depends on the performance of its work on a group of experts and specialists from around the world where the process of followup implementation through delegates who constitute committees for the exchange of experiences [13].

The adoption of the ISO standard is not a matter of necessity for institutions, but it helps them to win the confidence of customers or consumers. It contributes to raising the quality, safety, reliability and efficiency by optimal utilization of resources and making trade exchanges more free, balanced and progressive.

\section{Importance of applying ISO 9001:}

The importance of applying ISO 9001 is as follows [14]:
1- Improve the reputation of the institution with its suppliers and customers and achieve higher levels of performance.

2- Doing business correctly and minimizing monitoring of activities and processes.

3- Improve communications between different administrative levels.

4- Satisfying the needs and desires of customers where the products are designed according to their requirements and expectations.

5- Provide high quality products.

6- Increase productivity.

7- Raising the level of customer confidence towards the company's products and services.

8- Reduce the number of customer complaints related to quality.

9- Provide legal protection for the institution and protect it from any legal liability, through the necessary tests to ensure the safety of its products.

10-Ensure market share.

11-Dealing in the international markets.

\section{2- Research Objective:}

- Knowledge of the impact of quality management system ISO 9001:2015 on the breakdowns of machines in the General Company for the manufacture of wool and carpets in Hama.

- Clarifying the importance of applying ISO 9001:2015.

\section{3-Field study:}

-Company profile under study:

The practical part of this research will be applied to the general company for the manufacture of wool and carpets in Hama. In this part, we will present a study showing the impact of ISO 9001 on the breakdowns of machines in the company. The ISO 9001 standard will be applied in the company. By explaining to managers and heads of departments about the quality policy according to the international standard and reviewing the quality objectives and training the heads of departments on the work instructions and explain the basics of training and dissemination of work instructions on the bulletin board, then conducting a field study in the company to collect data and analysis and test hypotheses using appropriate statistical methods. The following is an overview of the company and its production types:

Is the only company in the Syrian Arab Republic that is sorting, washing and spinning wool.The company was established in 1978 under Decree No. 1198 with a capital of 70 million SP. 
The capital of the company was amended after the expansion of the second plant, with a capital of 723 million Syrian pounds. In accordance with the decision of the prime minister- chairman of the supreme council of planning No. 186 / dated 5/1/1995.

The company started producing the woolen yarn in 1981, which includes two production parts to prepare:

- * Sorting the production capacity / 3500 / ton per year and the classification of wool by lengths of fibers and diameter.

- *Laundry section has two production lines and production capacity / 7000 / ton per year.

And two factories for producing a half- combed yarn.

-Production types:

-Washed various wool suitable for making military blankets.

-White shear wools to feed the spinning mills in the company and to sell washed-out fabrics according to demand.

-Half-combed woolen yarns, dyed from leopard to provide automatic and manual carpet factories.

-Selling woolen yarns locally and abroad at competitive prices and international quality.

-Washing the wool with a fee and according to demand.

*The company seeks to expand its markets to include internal market and foreign markets.

*The company adopts international and Syrian specifications and can be manufactured according to any other standard.

*All the company's products enjoy international quality and good reputation in local markets. The company's engineers and technicians have excellent technical experience.

*The company obtained ISO / 9002 / quality certificate and was canceled.

*The company is committed to develop the quality of the performance of employees in accordance with the global system.

* Computerization has been introduced in the company since 1997, where the various works of the company have been completed, and a UNIX computer network has been installed to implement the programs and works of the company, computers have been expanded and programs have been introduced for each department in the company.

\section{Study variables:}

1- Independent variable: is the quality management system ISO $9001 \mathrm{X}$.

2- Dependent variable: is the breakdown of machines $\mathrm{Y}$.

$\mathrm{Y}=\mathrm{F}(\mathrm{X})$

\section{Study Hypothesis:}

There is one main hypothesis for the study: There is no statistically significant impact of the ISO 9001 quality management system in the company on machinery breakdowns.

\section{Research Methodology:}

The research uses the descriptive approach, which is based on the study of reality or phenomenon as it is in fact. This approach expresses the phenomenon studied in quantity and quality. The main hypothesis was put to decide the practical aspect of the research to accept or reject it as it answers questions about the phenomenon in question, it will be measured and verified using appropriate statistical analysis methods, in order to reach conclusions and proposals that contribute to achieve the research objectives.

\section{Community and Sample Research:}

The study community consists of all workers in the general company for the manufacture of wool and carpet in Hama, and the sample of the research is a small sample of employees in the company mentioned. The questionnaire was distributed to (40) workers from all the units selected to represent the community in question. After the forms were retrieved, they were sorted and entered into the computer, and the research was adopted on SPSS 19 for the statistical analysis.

\section{Building Research Tool:}

The questionnaire has been adopted as a research tool for being the most appropriate tool for achieving the research objectives. It supports and contributes to the basic information related to the subject, as well as the difficulty of obtaining information and data through other tools such as interviews, frequent field visits or personal observation. Design of the form based on studies and research on the subject of quality management system ISO 9001, note that this system is not applied in the company and has been applied as far as possible through interviews and an explanation of the work instructions of the specification.

The form consists of three sections arranged as follows:

1- The first section includes the questions related to the demographic characteristics of the members of the research sample represented by: (gender, age, certification, current work, experience, salary).

2- Section II: consists of phrases related to the independent variable quality management system ISO 9001, the number of phrases (6) phrases. 
3- Section III: consists of phrases related to the dependent variable (machinery breakdowns), and the number of phrases (4) phrases.

Each of its terms corresponds to a list of five options according to the five-caliber Likert scale [15] arranged as follows: (strongly agree, agree, neutral, disagree, strongly disagree). For statistical processing, the above options were given certain grades: strongly agree (5 degrees), agree (4 grades), neutral (3 grades), disagree (2 grades), strongly disagree (1 grade), and the questionnaire is valid for measuring the measurements prepared by:

\section{A- The apparent honesty:}

The questionnaire was presented to a number of arbitrators to determine its accuracy in measuring what was set up for it. The number of arbitrators for the questionnaire was 2 arbitrators from the Faculty of Economics at the University of Hama. In the light of the arbitrators' opinions, some of the phrases were modified, deleted, reworded, and other terms added. The form was finalized as follows:

\section{Part 1: Personal Data:}

1- Gender: male $\square$ female $\square$

2- Age: less than $30 \square$ 30-40 $\square$

More than 40

3- Certification: less than bachelor' degree $\square$ bachelor' degree $\square$ institute' degree $\square$ licence $\square$ master $\square \operatorname{PhD} \square$

4- Current work: administrative work

5- Experience: 1-5 $\square$ 6-10 worker $\square$

More than $10 \square$

6- Salary: less than 30 thousand $\square$ 30-40 thousand $\square$ more than 40 thousand

\section{Part II: Data on Variables:}

Please answer the following questions by making a correct mark to what you see fit:

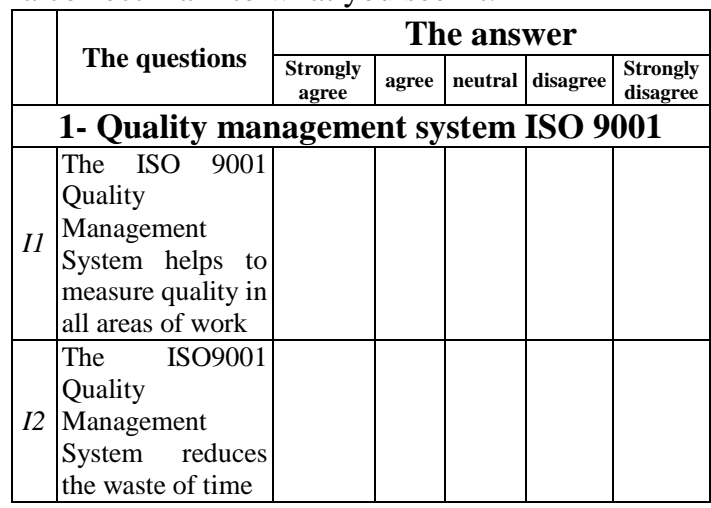

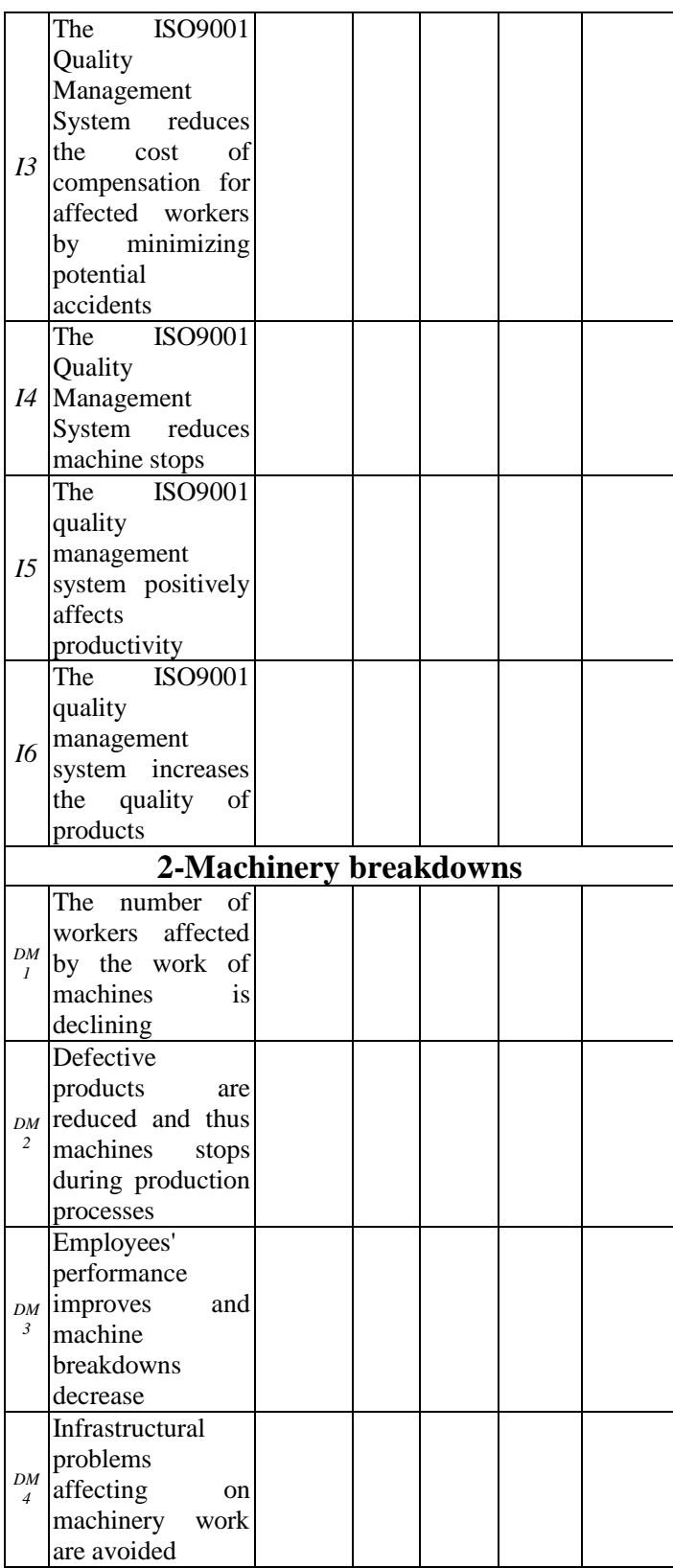

Note: Before the workers answered questions in the questionnaire, the working instructions for the international standard were explained.

-I: symbol indicates to the axis of quality management system ISO 9001.

- DM: symbol indicates the axis of machinery breakdowns.

\section{B- Stability of the measuring instrument (Reliability):}

The consistency test was performed on the research sample using the Alpha Cronbach coefficient. The measurement tool is consistently meant to be the internal consistency between its terms. The instrument has two aspects. The first is the stability of the scale that is the same results are obtained if the variable is measured in continuously. The other side of stability is objectivity, that is to say, regardless of the person who applies the test or 
designed it, the Alpha Cronbach correlation coefficient is between $0-1$ and until the measure is stable, the minimum value of the coefficient must not be less than (0.70) [16]. Table (1) shows the results of the Alpha Cronbach analysis for each section of the form.

Table (1) Alpha Cronbach coefficient of the research axes

\begin{tabular}{|c|c|c|}
\hline THE AXIS & $\begin{array}{c}\text { ALPHA } \\
\text { CRONBACH }\end{array}$ & $\begin{array}{c}\text { STABILITY } \\
\text { ASSESSMENT }\end{array}$ \\
\hline \multicolumn{3}{|c|}{ The first section: Quality management system ISO } \\
\hline $\begin{array}{c}\text { Quality } \\
\text { management } \\
\text { system ISO } \\
\mathbf{9 0 0 1}\end{array}$ & 0.871 & High \\
\hline \multicolumn{2}{|c|}{ The second section: Machinery breakdowns } \\
\hline $\begin{array}{c}\text { Machinery } \\
\text { breakdowns }\end{array}$ & 0.802 & High \\
\hline
\end{tabular}

The table was prepared based on the results of the statistical analysis of the questionnaire.

Note from Table (1) that the value of the Alpha Cronbach coefficient is greater than (0.70), indicating that the search tool is internally consistent between its phrases.

Where the value of the Alpha Cronbach parameter should not be less than 0.7 , and if the coefficient value is between 0.7 and 0.8 , the internal consistency between the terms is average, but if the parameter value is between 0.8 and 0.9 , the internal consistency of the terms is high, the parameter value is more than 0.9 The consistency between the terms is very high.

- Validity the search tool:

Researchers divide the validity of the scale into several types [17]:

*Content Validation:

This is also called the face validity, and aims to ensure the compatibility of the phrases contained in the measuring tool with the subject being studied, which is based on the judgment and personal assessment by researchers and accordingly the form was presented to a number of arbitrators and specialists in the field Management and Statistics at the Faculty of Economics at the University of Hama.

*Theoretical Validity:

The extent of reliance on the preparation of the measuring instrument in the study is based on previous theories and research and the accepted principles in the same field.

*Convergent Validity:

It determines the degree of coherence of concepts and phrases that measure the same thing with the total score of the scale. The higher the degree of correlation in the scale of all the variables or phrases to be measured, the more the measurement tool achieves the objective for which it is designed.

Based on the nature of the research, we have used the Exploratory Factor Analysis method, which aims to examine the data, for looking for a structure that expresses a set of variables and is a tool for reducing the data by using the Principle Component method and the maximum variation method (Varimax) that is vertical for the rotation of the correlation matrix axes. And the aim of rotation is to redistribute the variables' saturation to the factors so that the first factor or the first factors do not capture the greatest amount of saturations at the expense of the other factors [18], and the convergent validity of the used scale in the results of the analysis can be judged as follows:

1- The standard of variance rate: "the total explained variance for all factors", there is no minimum rate, yet researchers agree in the field of social sciences such as the economy that $60 \%$ or more acceptable [19].

2- Eigen values: The Eigen value of the factor must be at least 1 before it can be said to be statistically significant, and the Eigen value can be defined as: sum of the total variance extracted by the factor [20].

3- Saturation of factors: To know when the saturation of the factors is significant and statistically significant based on the size of the sample can be seen in Table (2) [21], which shows that, where the size of the sample in this research is equal to (40) form, saturation can be considered significant and statistically significant if the absolute value of that saturation is greater or equal to 0.55 .

Table (2) mean saturation according to sample size

\begin{tabular}{|c|c|}
\hline $\begin{array}{c}\text { The appropriate sample } \\
\text { size (greater or equal) }\end{array}$ & $\begin{array}{c}\text { Factor saturation (absolute } \\
\text { values) }\end{array}$ \\
\hline 350 & .300 \\
\hline 250 & .350 \\
\hline 200 & .400 \\
\hline 150 & .450 \\
\hline 120 & .500 \\
\hline 100 & .550 \\
\hline
\end{tabular}

-statistical analysis:

\section{1- Descriptive Statistics:}

\section{A. Distribution of the sample according to} the gender:

Table (3) distribution of the sample according to the gender

\begin{tabular}{|l|c|c|c|}
\hline Gender & Frequency & Percent & $\begin{array}{c}\text { Cumulative } \\
\text { percent }\end{array}$ \\
\hline Male & 37 & 92.5 & 92.5 \\
\hline Female & 3 & 7.5 & 100.0 \\
\hline Total & 40 & 100.0 & \\
\hline
\end{tabular}

\section{B. Distribution of the sample according to} the age:

Table (4) distribution of the sample according to the age

\begin{tabular}{|c|c|c|c|}
\hline Age & Frequency & Percent & $\begin{array}{c}\text { Cumulative } \\
\text { percent }\end{array}$ \\
\hline Less than 30 & 6 & 15 & 15 \\
\hline 30 to 40 & 18 & 45 & 60 \\
\hline
\end{tabular}




\begin{tabular}{|c|c|c|c|}
\hline More than 40 & 16 & 40 & 100.0 \\
\hline Total & 40 & 100.0 & \\
\hline
\end{tabular}

C. Distribution of the sample according to the certification:

Table (5) distribution of the sample according to the certification

\begin{tabular}{|c|c|c|c|}
\hline Certification & Frequency & Percent & $\begin{array}{c}\text { Cumulative } \\
\text { percent }\end{array}$ \\
\hline $\begin{array}{c}\text { Less than } \\
\text { bachelor }\end{array}$ & $\mathbf{1 6}$ & $\mathbf{4 0}$ & $\mathbf{4 0}$ \\
\hline $\begin{array}{c}\text { Bachelor' } \\
\text { degree }\end{array}$ & $\mathbf{1 1}$ & $\mathbf{2 7 . 5}$ & $\mathbf{6 7 . 5}$ \\
\hline Institute & $\mathbf{7}$ & $\mathbf{1 7 . 5}$ & $\mathbf{8 5}$ \\
\hline Licence & $\mathbf{6}$ & $\mathbf{1 5}$ & $\mathbf{1 0 0 . 0}$ \\
\hline Master & $\mathbf{0}$ & $\mathbf{0}$ & \\
\hline PhD & $\mathbf{0}$ & $\mathbf{0}$ & \\
\hline Total & $\mathbf{4 0}$ & $\mathbf{1 0 0 . 0}$ & \\
\hline
\end{tabular}

D. Distribution of the sample according to the current work:

Table (6) distribution of the sample according to the current work

\begin{tabular}{|c|c|c|c|}
\hline Current work & Frequency & Percent & $\begin{array}{c}\text { Cumulative } \\
\text { percent }\end{array}$ \\
\hline $\begin{array}{c}\text { Administrative } \\
\text { work }\end{array}$ & 9 & 22.5 & 22.5 \\
\hline Worker & 31 & 77.5 & 100.0 \\
\hline Total & 40 & 100.0 & \\
\hline
\end{tabular}

E. Distribution of the sample according to the experience:

Table (7) distribution of the sample according to the experience

\begin{tabular}{|c|c|c|c|}
\hline Experience & Frequency & Percent & $\begin{array}{c}\text { Cumulativ } \\
\text { e percent }\end{array}$ \\
\hline 1 to 5 & 3 & 7.5 & 7.5 \\
\hline 6 to 10 & 11 & 27.5 & 35 \\
\hline More than 10 & 26 & 65 & 100.0 \\
\hline Total & 40 & 100.0 & \\
\hline
\end{tabular}

F. Distribution of the sample according to the salary:

Table (8) distribution of the sample according to the salary

\begin{tabular}{|c|c|c|c|}
\hline Salary & Frequency & Percent & $\begin{array}{c}\text { Cumulative } \\
\text { percent }\end{array}$ \\
\hline Less than 30 & 4 & 10 & 10 \\
\hline 30 to 40 & 21 & 52.5 & 62.5 \\
\hline More than 40 & 15 & 37.5 & 100.0 \\
\hline Total & 40 & 100.0 & \\
\hline
\end{tabular}

\section{2-Results of the factor analysis:}

In order to reach at acceptable results through using the method of factor analysis applied in this research, the standards that are used for all axes related to the original variables of the study must have the Convergent Validity. To achieve this, the following conditions must be met:

1- The conditions for using the main factor analysis are:
A) The absolute value of the parameter of the correlation coefficients matrix is not equal to zero.

B) Pass the Kaiser-Meyer-Olkin (KMO) test to indicate the sufficiency of the sample size well, although the unacceptable limit is less than 0.50 [22].

C) To achieve the significant level of the Bartlett test, this requires that the value of this test be less than (0.05), to indicate the existence of at least some significant correlation between the variables, sufficient to use the factor analysis method.

2- The saturations of the standard phrases on each of the extracted factors shall be greater than the appropriate acceptance limit $(0.55)$ for the size of a sample less than (100) form. And all values of the Eigen values before the rotation for all the factors must be greater than one to achieve the criterion of the Eigen values.

3 - The percentage of interpreted variance by the combined factors must be greater than the minimum acceptable in social research $(60 \%)$ [23].

1- Validation the validity of the scale of Quality Management System ISO 9001axis:

In order to test the validation of the validity of the quality management system ISO 9001 axis, we must know the terms of this axis, which reflect the original variables, and are included in the following table:

Table (9) terms of the axis of quality management system ISO 9001:

\begin{tabular}{|c|c|}
$\begin{array}{c}\text { THE } \\
\text { SYMBOL }\end{array}$ & $\begin{array}{c}\text { THE PHRASES OF THE SCALE OF THE } \\
\text { FIRST AXES }\end{array}$ \\
\hline I1 & $\begin{array}{c}\text { The ISO9001 Quality Management System } \\
\text { helps to measure quality in all areas of work }\end{array}$ \\
\hline I3 & $\begin{array}{c}\text { The ISO9001 Quality Management System } \\
\text { reduces the waste of time }\end{array}$ \\
\hline I4 & $\begin{array}{c}\text { The ISO9001 Quality Management System } \\
\text { reduces the cost of compensation for affected } \\
\text { workers by minimizing potential accidents }\end{array}$ \\
\hline I5 & $\begin{array}{c}\text { The ISO9001 Quality Management System } \\
\text { reduces machine stops }\end{array}$ \\
\hline I6 & $\begin{array}{c}\text { The ISO9001 quality management system } \\
\text { positively affects productivity } \\
\text { increases the quality of products }\end{array}$ \\
\hline
\end{tabular}

The results of the factor analysis of the phrases that are representing quality management system ISO 9001 variables and the saturation of these variables by their representative factors can be included in the following table:

Table (10) results of the analytical analysis of the scale of the quality management system ISO 9001

\begin{tabular}{|c|c|}
\hline THE PHRASES OF & THE SATURATION OF \\
THE SCALE OF THE & THE FACTORS \\
\hline
\end{tabular}




\begin{tabular}{|c|c|}
\hline FIRST AXES & Factor1 \\
\hline I1 & $\mathbf{0 . 8 2 4}$ \\
\hline I2 & $\mathbf{0 . 5 4 5}$ \\
\hline I4 & $\mathbf{0 . 8 3 3}$ \\
\hline I5 & $\mathbf{0 . 8 8 8}$ \\
\hline I6 & $\mathbf{0 . 7 8 9}$ \\
\hline $\begin{array}{c}\text { The Eigen value before } \\
\text { the rotation }\end{array}$ & $\mathbf{0 . 8 5 5}$ \\
\hline $\begin{array}{c}\text { The Eigen value after } \\
\text { the rotation }\end{array}$ & $\mathbf{3 . 8 1 2}$ \\
\hline $\begin{array}{c}\text { The percentage of the } \\
\text { interpreted variance }\end{array}$ & $\mathbf{3 . 8 1 2}$ \\
\hline $\begin{array}{c}\text { The percentage of the } \\
\text { total interpreted } \\
\text { variance }\end{array}$ & $\mathbf{6 3 . 5 4 1}$ \\
\hline \multicolumn{2}{|c|}{ The table was prepared based on the results of the statistical } \\
\hline
\end{tabular}
analysis of the questionnaire.

It is clear from the previous table that a factor was extracted from all the phrases related to the variables of the Quality Management System ISO 9001. This factor was interpreted by $(63.541 \%)$ of the total variance of the terms in this axis and this factor carries the same axis name.

- The factor (Quality Management System ISO 9001): This factor was loaded six phrases, and this factor was interpreted as $(63.541 \%)$ of the total variance of terms.

The extracted factor for this axis can be represented according to the Scree Plot test which was created by the scientist Catel 1 as follows:

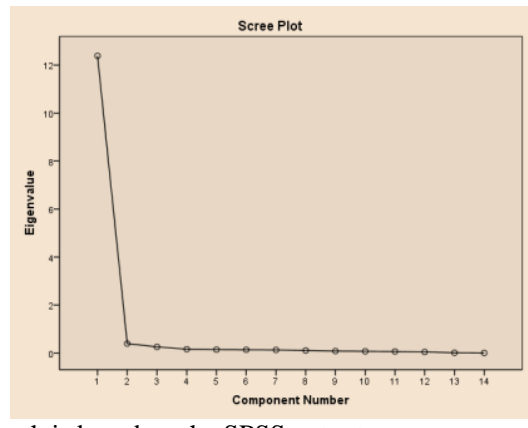

The graph is based on the SPSS output.

Figure (1) graph of Scree Plot Test for the axis of quality management system ISO 9001

From the above we can say that the used scales in this research regarding the axis or section related to the variables of the axis of the quality management system ISO 9001 all have the credibility of the Convergence Validity for the following reasons:

1- The conditions for using the main factor analysis are achieved:

- The absolute value of the parameter of the correlation coefficients matrix is not equal to zero, the value of the parameter here is Determinant $=0.014$.

- The Kaiser-Meyer-Olkin (KMO) scale is 0.719 and is larger than the desired limit
(0.70). This indicates that the size of the sample is well enough. The unacceptable limit is less than 0.50 .

- The Bartlett test is 0.000 , which is less than 0.05 , (0.05 is the level of significance in statistical analysis or probability of error, whereas most statistical analyzes are performed at a confidence level of 95\%), therefore the significant correlation between some variables are enough to use the method of factor analysis, and table (11) shows the results of the KMO and Bartlett test.

Table (11) results of the KMO and Bartlett testing for the quality management system ISO 9001

\begin{tabular}{|c|c|c|}
\hline \multirow{2}{*}{ KMO TEST } & \multicolumn{2}{|c|}{719.0} \\
\hline \multirow{3}{*}{ Bartlett TEST } & Approx. Chi-Square & 154.264 \\
\cline { 2 - 3 } & Degrees of freedom & 15 \\
\cline { 2 - 3 } & significance & 0.000 \\
\hline
\end{tabular}

The table was prepared based on the results of the statistical analysis of the questionnaire.

2- The saturations of the scale phrases on the extracted factor are strong and greater than the appropriate acceptance limit $(0.55)$ for a sample size less than 100. The value of the Eigen value before the rotation for the extracted factor is greater than one and is an achieved for the Eigen value criterion.

3 - The percentage of interpreted variance of the extracted factor is $(63.541 \%)$, which is higher than the accepted minimum in social research $(60 \%)$.

\section{2- Validation the validity of the scale of machinery breakdowns axis:}

In order to test the validation of the validity of the machinery breakdowns axis, we must know the terms of this axis, which reflect the original variables, and are included in the following table:

Table (12) terms of the axis of machine breakdowns

\begin{tabular}{|c|l|}
\hline $\begin{array}{c}\text { THE } \\
\text { SYMBOL }\end{array}$ & $\begin{array}{c}\text { THE PHRASES OF THE SCALE OF THE } \\
\text { SECOND AXES }\end{array}$ \\
\hline DM1 & $\begin{array}{l}\text { The number of workers affected by the work } \\
\text { of machines is declining }\end{array}$ \\
\hline DM2 & $\begin{array}{l}\text { Defective products are reduced and thus } \\
\text { machines stops during production processes }\end{array}$ \\
\hline DM3 & $\begin{array}{l}\text { Employees' performance improves and } \\
\text { machine breakdowns decrease }\end{array}$ \\
\hline DM4 & $\begin{array}{l}\text { Infrastructural problems affecting on } \\
\text { machinery work are avoided }\end{array}$ \\
\hline
\end{tabular}

The table was prepared according to the questionnaire prepared for this research

The results of the factor analysis of the phrases that are representing machinery breakdowns variables and the saturation of these variables by their representative factors can be included in the following table:

Table (13) results of the analytical analysis of the scale of the machinery breakdowns 


\begin{tabular}{|c|c|}
\hline $\begin{array}{l}\text { THE PHRASES OF THE } \\
\text { SCALE OF THE FIRST }\end{array}$ & $\begin{array}{c}\text { THE SATURATION OF } \\
\text { THE FACTORS }\end{array}$ \\
\hline AXES & $\begin{array}{l}\text { Factor1 } \\
\end{array}$ \\
\hline DM1 & 0.802 \\
\hline DM2 & 0.822 \\
\hline DM3 & 0.773 \\
\hline DM4 & 0.777 \\
\hline $\begin{array}{c}\text { The Eigen value before the } \\
\text { rotation }\end{array}$ & 2.522 \\
\hline $\begin{array}{c}\text { The Eigen value after the } \\
\text { rotation }\end{array}$ & 2.522 \\
\hline $\begin{array}{l}\text { The percentage of the } \\
\text { interpreted variance }\end{array}$ & 63.039 \\
\hline \begin{tabular}{|c} 
The percentage of the total \\
interpreted variance
\end{tabular} & 63.039 \\
\hline
\end{tabular}

It is clear from the previous table that a factor was extracted from all the phrases related to the variables of the machinery breakdowns. This factor was interpreted by $(63.039 \%)$ of the total variance of the terms in this axis and this factor carries the same axis name.

- The factor (machinery breakdowns): This factor was loaded four phrases, and this factor was interpreted as (63.039\%) of the total variance of terms.

The extracted factor for this axis can be represented according to the Scree Plot test which was created by the scientist Catel 1 as follows

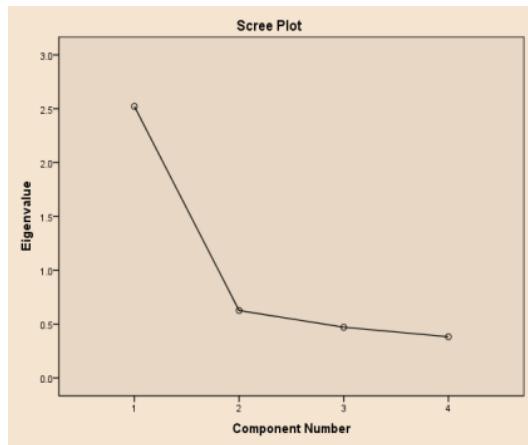

The graph is based on the SPSS output.

Figure (2) graph of Scree Plot Test for the axis of machinery breakdowns:

From the above we can say that the used scales in this research regarding the axis or section related to the variables of the axis of the machinery breakdowns all have the credibility of the Convergence Validity for the following reasons:

1- The conditions for using the main factor analysis are achieved:

- The absolute value of the parameter of the correlation coefficients matrix is not equal to zero, the value of the parameter here is Determinant $=0.284$.

- The Kaiser-Meyer-Olkin (KMO) scale is 0.767 and is larger than the desired limit (0.70). This indicates that the size of the sample is well enough. The unacceptable limit is less than 0.50 .

- The Bartlett test is 0.000 , which is less than $0.05, \quad(0.05$ is the level of significance in statistical analysis or probability of error, whereas most statistical analyzes are performed at a confidence level of 95\%), therefore the significant correlation between some variables are enough to use the method of factor analysis, and table (14) shows the results of the KMO and Bartlett test.

Table (14) results of the KMO and Bartlett testing for the machinery breakdowns

\begin{tabular}{|c|c|c|}
\hline KMO TEST & \multicolumn{2}{|c|}{767.0} \\
\hline \multirow{3}{*}{ Bartlett TEST } & Approx. Chi-Square & 46.406 \\
\cline { 2 - 3 } & Degrees of freedom & 6 \\
\cline { 2 - 3 } & significance & 0.000 \\
\hline
\end{tabular}

analysis of the questionnaire.

2- The saturations of the scale phrases on the extracted factor are strong and greater than the appropriate acceptance limit $(0.55)$ for a sample size less than 100. The value of the Eigen value before the rotation for the extracted factor is greater than one and is an achieved for the Eigen value criterion.

3 - The percentage of interpreted variance of the extracted factor is $(63.039 \%)$, which is higher than the accepted minimum in social research $(60 \%)$

\section{4- Results and Discussion:}

The researcher tested the hypothesis of the research statistically using SPSS 19 . The Regression Test was carried out in order to determine the significance of the regression models and calculate the regression parameters for all the studied variables, and then preparing the regression equations. We are adopted on FTest, T-Test to determine the significance of the resulting regression equations and the significance of the variables.

To determine whether there is a significant impact of ISO 9001 on machinery breakdowns, the researcher performed a regression analysis and the results were as follows:

Table (15) significance of the regression model of the axis of machinery breakdowns

\begin{tabular}{|c|c|c|c|c|c|c|}
\hline Model & $\begin{array}{c}\text { Sum of } \\
\text { Squares }\end{array}$ & df & $\begin{array}{c}\text { Mean } \\
\text { Square }\end{array}$ & F & Sig. & $\begin{array}{c}\text { Statistical } \\
\text { significance }\end{array}$ \\
\hline Regression & 3.844 & 1 & 3.844 & 82.289 & 0.000 & significant \\
\hline Residual & 1.775 & 38 & 0.047 & & & \\
\hline Total & 5.619 & 39 & & & & \\
\hline
\end{tabular}

Table (15) shows that the model of the axis of machinery breakdowns is significant, where the value of sig is $(0,000)$ which is smaller than 0.05 , this indicates there is a statistically significant impact of the quality management system ISO 9001:2015 on machinery 
breakdowns. Table (16) shows the significance of the regression model of machinery breakdowns.

Table (16) the parameters of the regression model of the axis of machinery breakdowns

Coefficients

\begin{tabular}{|c|c|c|c|c|c|c|}
\hline \multirow{2}{*}{ Model } & \multicolumn{2}{|c|}{$\begin{array}{l}\text { Unstandardized } \\
\text { Coefficients }\end{array}$} & \multirow{2}{*}{$\begin{array}{c}\begin{array}{c}\text { Standardized } \\
\text { Coefficients }\end{array} \\
\text { Beta } \\
\end{array}$} & \multirow{2}{*}{$\mathrm{t}$} & \multirow{2}{*}{ Sig. } & \multirow{2}{*}{$\begin{array}{c}\text { Statistical } \\
\text { significance }\end{array}$} \\
\hline & B & $\begin{array}{c}\text { Std. } \\
\text { Error }\end{array}$ & & & & \\
\hline \multirow{2}{*}{$\begin{array}{c}\text { Constant } \\
\text { variable }\end{array}$} & 1.005 & 0.399 & & 2.518 & 0.016 & significant \\
\hline & 0.777 & 0.086 & 0.827 & 9.071 & 0.000 & significant \\
\hline
\end{tabular}

Table (16) shows that the value of Sig is $(0,000)$ which is less than 0.05 , this indicates there is a statistically significant impact of ISO 9001:2015 on machinery breakdowns at a level of $5 \%$.

Thus the null hypothesis, that there is no statistically significant impact of the quality management system ISO 9001:2015 on machinery breakdowns, is rejected in favor of accepting the alternative hypothesis:

There is a statistically significant impact of the quality management system ISO 9001:2015 on machinery breakdowns.

From the above, the equation of regression model for the axis of machine breakdowns takes the following form:

$$
\begin{gathered}
\mathrm{Y}=\mathrm{b} 0+\mathrm{b} 1 \mathrm{X} \\
\mathrm{Y}=1.005+0.777 \mathrm{X}
\end{gathered}
$$

$\mathrm{Y}$ : The dependent variable in the regression equation which represents the breakdown of machines. $\mathrm{X}$ : Independent variable (Quality Management System ISO 9001) which affects the variable Y.

The correlation coefficient between the two variables $(\mathrm{R}=0.827)$ is a very strong correlation.

\section{5- Conclusions:}

The research presented a statistical study showing the impact of the quality management system ISO 9001:2015 on machinery breakdowns. The research was based on questionnaires in the general company for the manufacture of wool and carpets in Hama. Accordingly, the importance and role of the quality management system ISO 9001 in minimizing machine breakdowns and its impact will be reflected on the company's production in general, by adhering to the working standards of the international standard.

Based on the above, the researcher proposes to apply the ISO 9001:2015 standard in all administrative and productive parts (wool sorting, wool washing, yarn production). In the long term to obtain high quality woolen yarns at lower cost and higher productivity and meet customers' needs, and the market increases customer confidence towards their products.

Based on the results of the statistical analysis program (SPSS19), which were mentioned in the tables and figures in the practical part of this research, we find that there is a statistically significant impact of ISO 9001:2015 on machine breakdowns.

\section{References:}

[1] Tarek Al-Khir, "Using the Quality Control Maps in Industrial Public Sector Companies in Syria", Damascus University Journal Volume 17, No 2, 2001, P3.

[2] Carol, A. Reeves and David. A. Bedner, "Defining Quality Alternatives Implications, Academy of Management Review", Vol (19), 1994, P419-420.

[3] Raad Abdullah Al-Taai and Issa Kadada, "Total Quality Management", ed1, Dar Al Yazouri Scientific Publishing and Distribution, Amman / Jordan, 2008, P29.

[4] Ross, Joel, E, "Total Quality Management", second edition, USA Stlucie Press, 1995, P5.

[5] Amir Jamal al-Qayq, "The Extent of Implementing Quality Control in Auditing Offices in Gaza Strip", master thesis at the Islamic University, Gaza, 2012, P20.

[6] Grant, E.L. \& Leavenworth, R.S., "Statistical Quality Control", McGraw-Hill, 1980, P34.

[7] Shadi Aish, "The Impact of the Application of Total Quality Management on Institutional Performance", master thesis at the Islamic University, Gaza, 2008, P21.

[8] Praxiiom Research Group Limited "ISO: 2000 Translated into Plain English", Alberta, Canada, 2002, P78.

[9] Afnor, "ISO 9001 Quality Management System", exigencies, Paris, 2000, P8.

[10] Sawsan Shaker Majid and Mohamed Awad Al-Zyadat, "Total Quality Management and its Applications in Industry and Education", ed1, Dar Safa Publishing and Distribution, Jordan, 2007, P139.

[11] Craig Mesler, Thomas Flaif, "Pocket Guide to ISO 14000", Translation Center for Arabization and Programming, Dar AlArabia for Science, Beirut, 1999, P10.

[12] Khedeer Khazem Hamoud, "International Organization for Standardization", ed1, Dar Safa Publishing, Jordan, 2010, P56.

[13] Khalil Ibrahem and Mahmoud A-Ani, "Total Quality Management and ISO 9000", ed1, Al-Ashqar press, Iraq, 2002, P55-56. 
[14] Hamza Ben Al-Arabi, "The Contribution of the International Standard Specification (ISO) in Achieving and Developing the Competitive Advantage in the Economic Institution", master thesis at The Bouira University, Algeria, 2015, P 78.

[15] Aida Nakhla Rizkullah, "A Guide for Researchers in Statistical Analysis, Selection and Interpretation", Al-Bayan for Printing, Ain Shams University, 2002, P339.

[16] Hair, J.F, et al, "Multivariate Data Analysis", 5th Ed, Prentice - Hall International, INC, New York, 1998, P115.

[17] Hair F, et al, "Multivariate Data Analysis", 5th Ed, Prentice - Hall International, INC, New York, 1998, P117.

[18] Ahmed Al-Rifai Ghunaim, "Methods of Statistical Analysis", Dar Qbaa for Printing and Publishing, Cairo, 2000, P197.
[19] Aida Nakhla Rizkullah, "A Guide for Researchers in Statistical Analysis, Selection and Interpretation", Al-Bayan for Printing, Ain Shams University, 2002, P341.

[20] Hair, J.F, et al, "Multivariate Data Analysis", 5th Ed, Prentice - Hall International", INC, New York, 1998, P134.

[21] Aida Nakhla Rizkullah, "A Guide for Researchers in Statistical Analysis, Selection and Interpretation", Al-Bayan for Printing", Ain Shams University, 2002, P348.

[22] Leech, L N et al, "SPSS for Intermediate Statistics: Use and Interpretation", 2nd ED, Lawrence Erlbaum associates inc, New jersey, 2005, P245.

[23] Aida Nakhla Rizkullah," A Guide for Researchers in Statistical Analysis, Selection and Interpretation", Al-Bayan for Printing, Ain Shams University, 2002, P348.

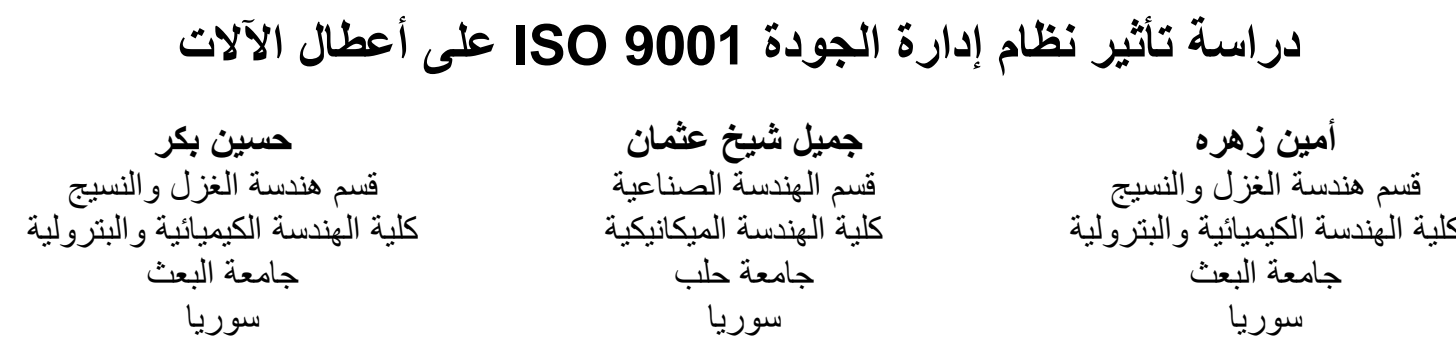

الخلاصة

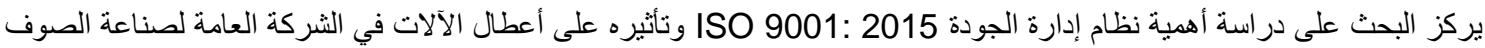

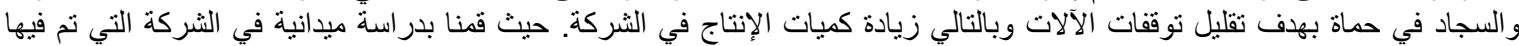

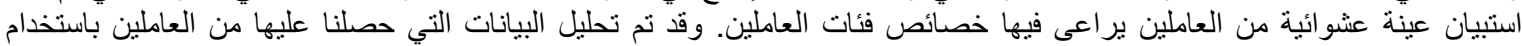

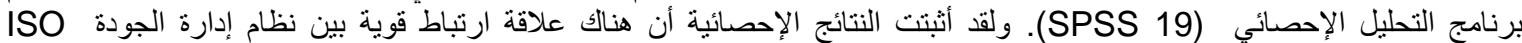

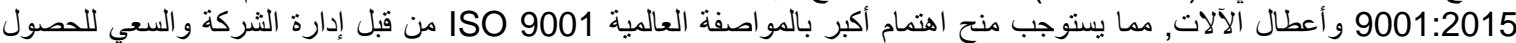

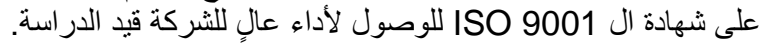

